\title{
HUBUNGAN DIAGNOSA KEPERAWATAN DENGAN PENGAMBILAN KEPUTUSAN
}

\author{
MUTIARA UNVI ZAHRA
}

\section{EMAIL : zahrazahrabatam845@gmail.com}

\section{LATAR BELAKANG}

Diagnosis keperawatan merupakan penilaian klinis terhadap pengalaman/respon individu, keluarga, atau komunitas pada masalah kesehatan/risiko masalah kesehatan atau pada proses kehidupan. Diagnosis keperawatan merupakan bagian vital dalam menentukan asuhan keperawatan yang sesuai untuk membantu klien mencapai kesehatan yang optimal. Sebagai seorang manusia kita pasti pernah sakit dan membutuhkan pelayanan kesehatan, dimana hal ini secara tidak langsung menyatakan bahwa kita membutuhkan bantuan orang lain terutama para tenaga kesehatan untuk membantu kita memenuhi kebutuhan pelayanan kesehtan.

Sebagai seorang perawat sudah sepatutnya kita berusaha yang terbaik dalam memberikan pelayanan yang terbaik kepada para pasien. Nah untuk mencapai hal itu pula sebelum memutuskan tindakan keperawatan perlu dilakukan diagnosis keperawatan sehingga keputusan tindakan kesehatan yang diberikan sesuai dengan kebutuhan pasien sehingga kesejahteraan, kesembuhan, dan kenyamanannya lebih mudah untuk dicapai. Adapun pengambilan keputusan merupakan suatu pemilihan dari berbagai alternatif dengan menetapkan suatu pilihan yang dianggap paling penting untuk memenuhi kepentingan tertentu.

Demikian halnya dalam keperawatan, pengambilan keputusan tindakan yang diberikan kepada seorang pasien akan mempengaruhi proses penyembuhan atau pelayanan yang diberikan. Untuk mengambil keputusan tersebut perlu dikakukan analisa berupa diagnosis keperawatan. Pengambilan keputusan dalam memilih pelayanan akan berdampak juga pada kepuasan dan kenyamanan pasien sebagai penerima pelayanan kesehatan. Kepuasan pasien ini dapat dijadikan sebagai tolak ukur kualitas dari suatu pelayanan kesehatan yang diberikan. Pelayanan kesehatan harus 
memiliki persyaratan dasar yang dapat memberikan penjelasan ataupun informasi sebelum klien menentukan pilihan terhadap penggunaan jasa pelayanan kesehatan. Pelayanan kesehatan yang diberikan hendaknya berkualitas baik sehingga didapati kepuasan tersendiri di dalam diri pasien maupun perawat itu sendiri. Pelayanan kesehatan dikatakan baik apabila pelayanan tersebut terjangkau, mudah dicapai, bermutu dan berkesinambungan dan tersedia bagi masyarakat umum tanpa ada diskriminasi.

Salah satu hal yang dapat mempengaruhi ketepatan ataupun ketidaktepatan keputusan pengambilan tindakan kesehatan oleh perawat yaitu diagnosis keperawatan. Diagnosis keperawatan dijadikan sebagai data lanjutan yang mendukung pengambilan keputusan setelah adanya data awal yang didapat dari pengkajian awal. Diagnosis keperawatan didapatkan oleh perawat dengan melakukan penelitian yang melibatkan pasien dan keluarga. Proses penentuan diagnosa pasien untuk memvalidasi, memperkuat dan menentukan prioritas masalah pasien dengan benar.

\section{METODE}

Metode yang saya gunakan dalam membuat kajian ini adalah dengan menggunakan metode literature review. Dimana saya membaca beberapa referensi seperti jurnal ataupun buku-buku yang mendukung. Jurnal jurnal serta buku maupun ebook yang saya gunakan saya kumpulkan memlaui media media seperti google scholar, e-book, maupun jurnal luar seperti Elsevier. Setelah membaca beberapa referensi, saya mengkaji dan membuat analisnya. Analisis dibuat sesuai thema judul yang saya ambil yaitu hubungan diagnosa keperawatan dengan pengambilan keputusan.

\section{HASIL}

Pengambilan keputusan dalam penyelesaian masalah adalah kemampuan mendasar bagi praktisi kesehatan, khususnya dalam asuhan keperawatan. Tidak hanya berpengaruh pada proses pengelolaan asuhan keperawatan, tetapi juga penting untuk meningkatkan kemampuan merencanakan perubahan. Perawat pada semua tingkatan posisi klinis harus memiliki kemampuan menyelesaikan masalah dan mengambil keputusan yang efektif, baik sebagai pelaksana/staf maupun sebagai pemimpin.

Penyelesaian masalah dan pengambilan keputusan bukan merupakan bentuk sinonim. 
Pemecahan masalah dan proses pengambilan keputusan membutuhkan pemikiran kritis dan analisis yang dapat ditingkatkan dalam praktek. Pengambilan keputusan merupakan upaya pencapaian tujuan dengan menggunakan proses yang sistematis dalam memilih alternatif. Tidak semua pengambilan keputusan dimulai dengan situasi masalah.

Pemecahan masalah termasuk dalam langkah proses pengambilan keputusan, yang difokuskan untuk mencoba memecahkan masalah secepatnya. Masalah dapat digambarkan sebagai kesenjangan diantara "apa yang ada dan apa yang seharusnya $a d a "$. Pemecahan masalah dan pengambilan keputusan yang efektif diprediksi bahwa individu harus memiliki kemampuan berfikir kritis dan mengembangkan dirinya dengan adanya bimbingan dan role model di lingkungan kerjanya.

Diagnosis merupakan proses tindakan keperawatan dalam menentukan jenis penyakit berdasarkan tanda dan gejala dengan menggunakan cara dan alat seperti laboratorium, foto, dan klinik. Diagnosis keperawatan dijadikan sebagai data lanjutan yang mendukung pengambilan keputusan setelah adanya data awal yang didapat dari pengkajian awal. Diagnosis keperawatan merupakan kesimpulan yang dihasilkan dari pengkajian data dengan penelitian. Diagnosa keperawatan juga merupakan langkah kedua dari proses keperawatan yang menunjukkan penilaian klinis tentang respon klien baik itu individu, keluarga, kelompok maupun masyarakat terhadap permasalahan kesehatan yang dialami.

Oleh karena itu dengan tepatnya diagnosis keperawatan maka permasalahan kondisi kesehatan pasien akan diketahui dan dengan diketahuinya permasalahan kesehatan yang dialami maka akan dihasilkan solusi yang tepat untuk menunjang kesembuhan pasien. Dengan kata lain, jika diagnosis keperawatan yang dirumuskan tidak tepat atau masih jauh dari masalah kesehatan yang dialami pasien, maka keputusan pengambilan tindakan kemungkinan besar tidak tepat. Sehingga solusi atau tindakan keperawatan yang diberikan tidak sesuai dengan kebutuhan pasien yang dapat memperlama waktu perawatan pasien atau bahkan lebih lama mendapatkan hak sebagai pasien berupa kesejahteraan, kesembuhan maupun kenyamanan.

\section{PEMBAHASAN}


Diagnosa keperawatan adalah keputusan klinis tentang respons individu, keluarga, atau komunitas terhadap masalah kesehatan yang actual dan potensial, atau proses kehidupan. Diagnosa keperawatan merupakan suatu pernyataan yang menjelaskan respon manusia. Status kesehatan atau risiko perubahan pola 2 dari individu atau kelompok dimana perawat secara akuntabilitas dapat mengidentifikasi dan memberikan intervensi secara pasti untuk menjaga status kesehatan, membatasi, mencegah, atau mengubahnya. diagnosa keperawatan adalah masalah kesehatan actual dan potensial dimana berdasarkan pendidikan dan pengalamannya, ia mampu dan mempunyai kewenangan untuk memberikan tindakan keperawatan.

Diagnosa keperawatan sebagai keputusan klinis mengenai individu, keluarga, atau masyarakat yang diperoleh melalui suatu proses pengumpulan data dan analisis cermat dan sistematis, memberikan dasar pembuatan ketentuan + ketentuan untuk terapi yang pasti dimana perawat bertanggung jawab. Jadi, dari beberapa pendapat diatas dapat disimpulkan bahwa diagnose keperawatan adalah keputusan klinis mengenai respon individu, keluarga, atau masyarakat yang diperoleh melalui proses pengumpulan data terhadap masalah kesehatan yang aktual maupun potensial guna menjaga status kesehatan.

Menurut KBBI, dinyatakan bahwa diagnosis merupakan penentuan jenis penyakit dengan cara meneliti (memeriksa) gejalagejalanya; pemeriksaan terhadap suatu hal. Di dalam kesehatan, diagnosis merupakan proses tindakan keperawatan dalam menentukan jenis penyakit berdasarkan tanda dan gejala dengan menggunakan cara dan alat seperti laboratorium, foto, dan klinik.

Diagnosis keperawatan dijadikan sebagai data lanjutan yang mendukung pengambilan keputusan setelah adanya data awal yang didapat dari pengkajian awal. Diagnosis keperawatan merupakan kesimpulan yang dihasilkan dari pengkajian data dengan penelitian. Diagnosa keperawatan juga merupakan langkah kedua dari proses keperawatan yang menunjukkan penilaian klinis tentang respon klien baik itu individu, keluarga, kelompok maupun masyarakat terhadap permasalahan kesehatan baik aktual maupun potensial.

Perawat memiliki cara dan kompetensi untuk mengatasinya . Adapun Komponen diagnosa keperawatan menurut PPNI Tahun 2010 terdiri dari masalah (P), etiologi atau penyebab (E) dan tanda atau gejala (S) atau terdiri dari masalah dengan disertai penyebab 
(PE). Diagnosis keperawatan didapatkan oleh perawat dengan melakukan penelitian yang melibatkan pasien dan keluarga. Penentuan diagnosis pasien bermanfaat untuk memvalidasi, memperkuat dan menentukan prioritas masalah pasien dengan benar. Sesuai dengan UU No. 38 Tahun 2014, perawat berwenang untuk menegakkan diagnosis keperawatan dalam proses menjalankan tugas sebagai pemberi asuhan keperawatan.

Sebelum merumuskan diagnosis keperawatan perlu dilakukan analisis data yang merupakan kemampuan kognitif dalam mengembangkan kemampuan berpikir dan penalaran seorang perawat yang dipengaruhi oleh latar belakang pendidikan, ilmu dan pengetahuan yang dimilikinya. Di dalam melakukan analisis data dimulai dengan mengelompokkan data yang diperoleh dari anamnase, observasi dan pemeriksaan fisik dengan hasil yang didapat dari perbandingan hasil pemeriksaan dengan kondisi standar atau normal. Dengan begitu, masalah kesehatan yang dialami pasien akan diketahui dan dapat merumuskan diagnosis keperawatan sebagai tindakan lanjut sebelum menentukan putusan pengambilan tindakan perawatan.
Pengambilan keputusan sangat penting keberadaannya dalam asuhan maupun dalam manajemen keperawatan. Pengambilan keputusan merupakan suatu proses yang mencakup semua penilaian kegiatan yang diperlukan guna membuktikan dan meperlihatkan pilihan terbaik dalam menyelesaiakan suatu masalah tertentu. setiap keputusan adalah akibat dari sebuah proses dinamis yang dipengaruhi oleh banyak kekuatan, pengambilan keputusana bukan merupakan prosedur yang tetap akan tetapi sebuah proses yang beruntun. pengambilan keputusan adalah proses yang melibatkan pendekatan sistemik yang harus diadaptasikan dengan lingkungan. Bagaimanan perawat dalam mengambil keputusan klinis? Pengambilan keputusan keperawatan dilakukan pada semua tahap proses keperawatan. Sehingga seorang perawat harus mampu berpikir ktitis, berkomunikasi dengan baik sebagai suatu elemen penting dalam pengaambilan keputusan klinis, sehingga terjadi pembelajaran berkelanjutan bagi pasien sehingga meningkatkan tingkat kemandirian pasien.

Definisi lain dijelaskan bahwa pengambilan keputusan klinis keperawatan merupakan serangkaian keputusan yang dibuat oleh perawat, dalam interaksi dengan klien 
mengenai pengkajian yang didapat dari klien, evaluasi data yang diamati, variasi diagnosa yang muncul serta tindakan keperawatan yang harus diambil. Teori yang dikemukakan oleh Buckingham and Adams pengambilan keputusan klinis merupakan perilaku klasifikasi.

Klasifikasi dapat diartikan bahwa pengambilan keputusan merupakan sebuah pola tertentu sama halnya dengan proses keperawatan, jelas bahwa dalam setiap proses keperawatan perawat harus mampu mengambil keputusan klinis. Sedangkan menutut Guyatt menjelaskan bahwa asuhan yang berdasarkan evidence base pengambilan keputusan harus melibatkan pasien. Sehingga penting bagi perawat untuk mampu mengambil keputusan dengan baik, cepat dan akurat dalam hal ini menurut Sumijatun perlu dipahami bagi perawat bahwa pengambilan keputusan klinis dengan melibatkan klien akan erat hubungannya dengan nilai-nilai budaya yang dianut oleh klien.

Ketepatan pengambilan keputusan akan di pengaruhi oleh kompentisi perawat, kemampuan berkomunikasi, lingkungan serta budaya. Penting bagi perawat untuk selalu meningkatkan kapasitas dirinya dalam pemberian asuhan keperawatan hal ini akan meningkatkan kepercayaan masyarakat terhadap perawat yang selanjutnya akan meningkatkan profesionalisme perawat.

Hal ini bisa digunakan sebagai acuan dalam melakukan hubungan interdisiplin. Pengambilan keputusan yang tepat akan meningkatkan kemandian klien dalam asuhannya serta membantu klien untu menentukan pilihan bantuan yang tepat sesuai dengan kondisinya. Klien yang mandiri akan menurunkan beban kerja perawat sehingga pelayanan keperawatan akan lebih efektif dan efisien dalam penggunaan sumber daya.

\section{PENUTUP}

Diagnosis keperawatan merupakan proses tindakan keperawatan dalam menentukan jenis penyakit berdasarkan tanda dan gejala dengan menggunakan cara dan alat seperti laboratorium, foto, dan klinik. Diagnosis keperawatan dijadikan sebagai data lanjutan yang mendukung pengambilan keputusan setelah adanya data awal yang didapat dari pengkajian awal. Diagnosis keperawatan merupakan kesimpulan yang dihasilkan dari pengkajian data dengan penelitian. Pengambilan keputusan sendiri merupakan suatu pemilihan dari berbagai alternatif dengan menetapkan suatu pilihan yang dianggap paling penting untuk memenuhi 
kepentingan tertentu. Pengambilan keputusan tyang diberikan kepada seorang pasien akan mempengaruhi proses penyembuhan atau pelayanan yang diberikan. Untuk itu mengambil keputusan perlu dikakukan dengan analisa berupa diagnosis keperawatan. Maka dengan tepatnya diagnosis keperawatan permasalahan kondisi kesehatan pasien akan diketahui dan dengan diketahuinya permasalahan kesehatan yang dialami maka akan dihasilkan solusi yang tepat untuk menunjang kesembuhan pasien. Jadi, rumusan diagnosis keperawatan berpengaruh terhadap pengambilan keputusan tindakan terhadap pasien.

\section{DAFTAR PUSTAKA}

Ainun, I. N. (2019) Dasar - Dasar Penentuan Diagnosa Dalam Asuhan Keperawatan. Osf.io

* Alligood, Martha Raile and Ann Marriner Tomey. (2012) Nursing Theorist and Their Work (sixth edition). Elsevier Mosby

* Apriyani, Heni. (2015). Identifikasi Diagnosis Keperawatan Pada Pasien Di Ruang Paru Sebuah Rumah Sakit. Jurnal Keperawatan. 11(1)
Budiono \& Sumirah,B,P.(2016). Konsep Dasar Keperawatan (Ed 2). Jakarta. Bumi Medika.

* Cikwanto. (2017). Pengembangan Instrumen Penegakan Diagnosis Keperawatan Berbasis Standar Diagnosis Keperawatan Indonesia (Sdki). Development Of Nursing Diagnosis Instrument Based On Standardized Nursing Diagnosis Indonesia

Cikwanto dan Nupiyanti. (2018). Pengembangan Instrumen Penegakan Diagnosis Keperawatan Pada Pasien Congestive Heart Failure (Chf) Berbasis Standar Diagnosis Keperawatan Indonesia (Sdki). Jurnal Keperawatan Aisyiyah (JKA). $5(1)$

Hidayah, Nur. (2014). Manajemen model asuhan keperawatan profesional (MAKP) tim dalam peningkatan kepuasan pasien di rumah sakit. Jurnal Kesehatan, 7(2). 114-141.

* Khairina. Ifa, Hema Malini, Emil Huriani. 2018. Faktor-Faktor yang Berhubungan dengan Pengambilan Keputusan Perawat Dalam Ketepatan Triase Di Kota Padang. Indonesian Journal For Heath Science. 2(1) 
Layuk, Elim. (2017). Pengaruh pengetahuan, sikap, dan keterampilan perawat terhadap kepuasan pasien rawat inap di RS labuang Baji Makassar. Jurnal Mirai Management..2(2).

Lingga, B. Y. (2019). Keberhasilan

Diagnosa Keperawatan Menentukan Potensi Dan Kompetensi Perawat

* Mehee An and Robert J Palisono. Family- profesional in pediatric rehabilitation: a practice model. Informa UK Ltd.

* Panggabean, Nabila Salsabila. 2019. Berpikir Kritis Dalam Mengambil Keputusan. Osf.io
Simamora, R. H., Bukit, E., Purba, J. M., \& Siahaan, J. (2017). Penguatan kinerja perawat dalam pemberian asuhan keperawatan melalui pelatihan ronde keperawatan di rumah sakit royal prima medan. Jurnal pengabdian kepada masyarakat, 23(2), 300-304.

Simamora, R. H. (2019). Socialization of Information Technology Utilization and Knowledge of Information System Effectiveness at Hospital Nurses in Medan, North Sumatra. Editorial Preface From the Desk of Managing Editor..., 10(9). 